\begin{tabular}{|c|c|}
\hline & Volume \& Issues Obtainable at The Women University Multan \\
Annals of Social Sciences and Perspective \\
ISSN: 2707-7063, Volume 2, No.2 December 2021
\end{tabular}

\title{
Interaction between Law and Morality: The Philosophical Construct
}

\author{
Muhammad Danyal Khan', Muhammad Mumtaz Ali Khan², Imran Alam³
}

${ }^{1}$ University Gilani Law College, Bahauddin Zakariya University, Multan

${ }^{2}$ Director, Research and Development, Punjab Higher Education Commission Lahore

${ }^{3}$ Assistant Professor, University Law College, University of the Punjab Lahore

\begin{tabular}{|c|c|c|}
\hline \multicolumn{2}{|c|}{ ARTICLE DETAILS } & \multirow{3}{*}{$\begin{array}{l}\text { ABSTRACT } \\
\text { This paper discusses the jurisprudential analysis of } \\
\text { law and legislation in a modern state. The main } \\
\text { objective of this analysis is to ascertain the role and } \\
\text { status of morality in the modern constitutional } \\
\text { setup. Various views of legal positivism will be } \\
\text { probed in light of the role of morality in } \\
\text { codification. The study will comprise upon doctrinal }\end{array}$} \\
\hline $\begin{array}{l}\text { History: } \\
\text { Received: } \\
\text { Review: } \\
\text { Accepted: } \\
\text { Available Online: }\end{array}$ & $\begin{array}{l}\text { November 18,2021 } \\
\text { November 22, } 2021 \\
\text { December 21, } 2021 \\
\text { December 22, } 2021\end{array}$ & \\
\hline \multicolumn{2}{|l|}{ Keywords: } & \\
\hline \multicolumn{2}{|l|}{ Law } & $\begin{array}{l}\text { analysis of various positivist writers of the } 20^{\text {th }} \\
\text { century. Contemporary elements of law in the }\end{array}$ \\
\hline \multicolumn{2}{|l|}{ Morality } & modern nation-state system are more pro-positivist \\
\hline \multicolumn{2}{|l|}{ Legal Positivism } & $\begin{array}{l}\text { in approach rather than moral. In the light of these } \\
\text { elements, the reader will understand the scope of }\end{array}$ \\
\hline \multicolumn{2}{|l|}{ Naturalist } & $\begin{array}{l}\text { morality especially religious morality in the } \\
\text { contemporary legal framework. A comparative }\end{array}$ \\
\hline \multicolumn{2}{|l|}{ Interpretative } & analysis will explain the standards of both theories \\
\hline \multicolumn{2}{|l|}{ Jurisprudence } & $\begin{array}{l}\text { of legal positivism and naturalist interpretation of } \\
\text { laws. }\end{array}$ \\
\hline & & $\begin{array}{l}\text { (c) } 2021 \text { The Authors, Published by WUM. This is an Open Access } \\
\text { Article under the Creative Common Attribution Non Commercial4.0 }\end{array}$ \\
\hline
\end{tabular}

10.52700/assap.v2i2.110

Corresponding author's email address: mumtaz.ali@punjabhec.gov.pk

\section{Introduction}

The theory of legal positivism replaced the naturalist school of thought that prevailed over standards of legal codification in the past several centuries. The main subject of law in society. Legal theories under various schools of thought struggle to survive transforming societies with their flexible and vibrant approach while some of them lose significance because of non-compatibility with novel standards of society. Historical jurisprudence, established by Sir Hennery Maine and Carl Sevigny are examples. This phenomenon is explained by Joseph Raz as: "Because legal theory attempts to capture the essential features of the law, as encapsulated in the self-understanding of a culture, it has a built-in obsolescence, since the self-understanding of cultures is forever changing" (Bix, 2005, p.29). Besides fading of various schools of thought in history and the advent of legal positivism, 
natural law theory has been in discussion for centuries. Contemporary era witnesses a great debate between proponents of natural law theory and legal positivism. There is a perspective on the impossibility of elimination of the role of morality in codification while others support their positivist stance on the analogy of modern nation-state based on rights and sovereignty. Our era of the scientific age has witnessed flourishing trends of legal positivism and its compatibility with the nation-state system (Bix, 2005, p.29).

The theory of legal positivism is almost two centuries old. The theory stems from the writings of Jeremy Bentham (1748-1832) and English jurist Thomas Hobbes (1588-1679). Brain H. Bix explains the main objective of legal positivism as, 'an effort to establish a study of the nature of law, disentangled from proposals and prescriptions for which laws should be passed or how legal practice should be maintained or reformed (Bix, 2005, p.29).' The writings of John Austin are considered as a foundation to modern concepts of legal positivism, and he states:

"The stance of law is one thing; its merit or demerits in another. Whether it be or not be is one inquiry; whether be or be not confrontable to an assumed standard, is a different inquiry. A law, which exists, is a law, though we happen to dislike it, or thought it varies from text, by which we regulate our approbation and disapprobation."(Austin, 1995, p.157)

The writings of John Austin, Hans Kelsen started a major shift like law. It was a clear shift from political and moral standards to the scientific organization of law based upon rights and duties recognized and protected by a sovereign state. Kelson out ruled the nature of law as of sociologist. He thought the law is more practical in its approach rather than theoretical (Kelson, 1934, p.7). This was a time of legal realism that means a study of law scientifically and practically. This study will be free from all historical, religious, and cultural influences. From a scientific approach towards law, it is meant that the approach will be objective rather than subjective. The laws will be promulgated based on rights and duties, not their moral values. Legal positivism is a theory that focuses on basic elements of the law. It segregates law from what is not law. This was a clear shift from the idea of natural law thinkers.

The theory of natural law may be traced back to the era of Greeks and Romans in the shape of philosophical endeavors of Stoics and Aristotle. These thoughts were refined by Thomas Aquinas and John Finnis (George, 1992, p. 31). The concept of natural law may be called legal-moralism to settle down the normativity of law (George, 2008, p.171). The main philosophy of Naturalism revolves around the law as a tool to protect the collective moral standards in society and a comprehensive standard of the good life. It is believed that there is a superior legal norm that must be followed by the legislature to form a good law otherwise codification will be defective. This higher law or moral law arises from firm self-evident values that exist in human society and are widely recognized. This higher or moral law can be perceived by reason and is universally accepted (Demiray, 2015, p.807). Robert P. George comments:

"Law schools do not (or do not only) teach their students moral philosophy, but focus the attention of students on distinctive techniques of legal analysis... we must be careful to distinguish a different metaphysical order that attaches to the moral purpose of the law. It is in the order of "doing" (the order of free choice, practical reasoning, and morality) that we identify the need to create law for the sake of the common good. The legislator creates a cultural object-that is, the law which is deliberately 
and reasonably subject to technical analysis, for the purpose that is moral and not merely technical." (Campbell, 1879, p. 324)

This idea depicts that legislation in a state is a technique to form a common good in society and that the common goodwill enforcement of morality is superior law. This idea of moral realism establishes the superiority of norms over the codified law. Naturalist thinkers believe that the state has to protect the morality of society. Natural Law Theory is in direct contrast with legal realism and legal positivism.

It may be stated that proponents of the Natural Theory of Law want laws subservient to moral code and legal positivists wish the law to operate independently of all external checks and want to establish legal realism instead of moral realism. This legal realism and legal positivism demand liberation of law from all influence and operate independently under a system of the state. Contemporary writings of H.L.A. Hart and Joseph Raz demonstrate this trend where it is suggested that law itself is a norm and does not follow some external factors. The normativity of law is rights and duties recognized by law, not by morality.

\section{Austin's Approach towards Law-making}

John Austin is one of the founders of Legal Positivism. He was the proponent of the dichotomy of morals and law. His visualization of law was what it is and not what it ought to be? He followed his predecessors in Legal Positivism as Thomas Hobbes and Jeremy Bentham. The ideas of Austin are of Analytical Jurisprudence. He described the law as a sovereign command that is backed by positive and negative sanctions. According to Austin, a law should be a proper law not the dictates of morality. From the word proper law, he suggests a law that stems from sovereign authority or its delegates. He accepts moral or divine law only in case it is promulgated through sovereign authority (Austin, 1995, p.215). John Austin maintains that there exist two facets of authority in a society. One is spiritual and the other is a sovereign state. He further states that only positive law or codified law of the state is subject of jurisprudence while injections of divine belong to theological studies (Austin, 1995, p.215). Austin attributed law as some mechanism construed by private society for the protection of legal rights. He exemplified law as some rules introduced by a guardian for the ward. He attributed the sovereign as guardian of society and the masses as wards. Sovereign promulgates law for its masses to protect their rights as well as society (Austin, 1995, p.215). Austin's approach towards law is of commands introduced by a sovereign with the backing of sanctions.

Austenian concept divides legal process among three basic concepts of political sovereign, command, and sanction. Here, the source of law is sovereign not something spiritual or metaphysical rather an authority made by members of society themselves or one among them. Status of law will be given to specific commands issued by a sovereign to enforce them through sanction. His concept of command is imperative that creates duty and violation of the duty will inflict sanction (Austin, 1995, p.215). Austin further explained command and differentiated it from some laws which do not truly fit his imperative version of the law. He explained them as declaratory laws, repealing laws and laws for the imperfect obligation. Austin, in his theory, divided jurisprudence into legal positivism and moral positivism. He considers those commands as laws that are creating rights and duties from a sovereign (Austin, 2002, p.135). He attributes sovereigns as morally bound to follow collective morality but in case of codification of law against moral standards of society but still, the codified law 
will prevail. He explains that when there is a struggle between legal positivism and moral positivism, legal positivism will triumph (Austin, 2002, p.1350. The work of Austin bears a reflection of Bentham's work as he declares law as what is the will of the sovereign. Jeremy Bentham's view is described in his own words, "Law is defined as an assemblage of signs declarative of volition conceived or adopted by the sovereign in a state, concerning the conduct to be observed in a certain case by a certain person or a class of persons, who in the case in question are subject to his power." Bentham was utilitarian in his approach towards law as he described it as a tool to maximize pleasure and minimize the pain of an individual while John Austin laid the foundation of the contemporary jurisprudential foundation of codification.

Austenian conceptualization of law has been criticized by many authors on the analogy of absolutism of state authority. It may be said that the law without morality will lead towards the absolute rule of monarch or authority where the will of people will have no weightage. In this regard, these allegations are answered on the notion of acceptance of morality by the thinker as some object that plays a pivotal role in the codification of law but once it is codified, there is no room for morality or testing of codified law as the morality is an abstract concept and may vary with plural ideas in the same society. But the basic characteristic of law is it idea of certainty. If the law is tested and challenged based on something that may be interpreted in various ways, it will open a way for uncertainty in the operation of law. This approach is attacked on the analogy of interpretation of the law by judges. In this case, judges also maintain a difference of opinion on certain laws through precedents. The answer to this criticism is that the interpretation of the statute by the judges in various cases is once again under the sovereign authority of the state and interpretation follows certain cannons and maxims. This phenomenon of interpretation of the law under the authority of the state is similar to Austenian ideals of law.

The contemporary foundation of the legislative process in democratic nation-states follows the standards of law expounded by Austin and Jeremy Bentham which were further elaborated by H.L.A. Hart and Ronald Dworkin (Bhardwaj, 2015, p. 7). Legal Positivism is one of the most significant schools of jurisprudence. The writings of Austin and Bentham liberated law from the external impacts of morality and divinity. This led towards the establishment of law as a science that calls for a systematic study of rights and duties ascertained by society itself not the external or metaphysical factors.

\section{H.L.A Hart on Legal Positivism}

H.L.A Hart was a $20^{\text {th }}$-century legal jurist who forwarded the idea of Legal Positivism that somehow recognized the significance of morality. He considers morality as one of the sources for codification but shares his ideals of Legal Positivism with Austin and Kelson in attributing morality as not superior to codified law. He reflected law and morality as neighboring concepts but not necessarily related (Bentham, 2008, p. 79). Hart approves maxims of justice in a legal system and does not rule out them completely. He comments that the law should act similarly in some cases and differently in different cases (Star, 1984, p.673). Moral standards play a significant role in the formation of the legal system in the view of H.L.A Hart writings as he says that while adjudicating a certain matter, a judge should act impartial and his own words, "Prejudice, interest, or caprice." (Hart, 1994, p.155) He further explains the operation of law as noted, "though that most odious laws may be justly applied, we have, in the bare notion of applying a general rule of law, the germ at least of justice" (Hart, 1994, p. 202). He describes the law as a tool for social control. The concepts 
of fairness, formal justice, and impartiality are recognized by the writings of H.L.A. Hart and it is a mere misconception that positivism rules out morality from the operation of law rather do not let morality control the law. The relationship of law and morality is explained by Hart as:

The law of every modern state shows at a thousand points the influence of both the accepted social morality and wider moral ideals. These influences enter into law either abruptly and avowedly through legislation, or silently and piecemeal through the judicial process. In some systems, as in the United States, the ultimate criteria of legal validity explicitly incorporate principles of justice and substantive moral values; in other systems, as in England, where there are no formal restrictions on the competence of the supreme legislature, its legislation may yet no less scrupulously conform to justice or morality. The further ways in which law mirrors morality are myriad, and still insufficiently studied: statutes may be a mere legal shell and demand by their express terms to be filled out with the aid of moral principles; the range of enforceable contracts may be limited by reference to conceptions of morality and fairness; liability for both civil and criminal wrongs may be adjusted to prevailing views of moral responsibility. No "positivist" could deny that these are facts, or that the stability of the legal system depends in part upon such types of correspondence with morals. If this is what is meant by the necessary connexion of law and morals, its existence should be conceded." (Hart, 1994, p. 202)

H.L.A Hart describes his philosophy of law by dividing laws into primary and secondary rules and describes the relationship between the two in his famous work, The Concept of Law. He describes law as close and independent field of study. Hart believes that two types of rules form the foundation of law and those are primary and secondary rules. He opined that "law may most illuminatingly be characterized as a union of primary rules of obligation with such secondary rules." (Hart, 1994, p. 202). From primary rules, Hart means, the rules impose a duty. These are meant for the imposition of duty by the state on individuals through legislation. He names primary rules as basic rules. These rules explain what an individual is allowed to do and what one cannot do under codified law. For example traffic rules, contract rules, and other statutory or codified commands to act or not to act in certain situations. Those rules are generally perceived by the masses as state laws. Hart explains them as:

"Under rules of the one type, which may well be considered the basic or primary type, human beings are required to do or abstain from certain actions, whether they wish or not. Rules of the other type are in a sense parasitic upon or secondary to the first; for they provide that human beings may by doing or saying certain things introduce new rules of the primary type, extinguish or modify old ones, or in various ways determine their incidence or control their operation. Rules of the first type impose duties; rules of the second type confer powers, public or private." (Hart, 1994, p. 151)

Secondary rules do not impose duties. They confer upon various organs of state to formulate execute primary rules. Secondary rules explain the way primary rules are recognized and judicially decided. They describe the procedure of formation of primary rule and further enforcement mechanism. To illustrate, laws against street crimes are primary rules as they state what cannot be done and what will be the punishment in case of any street crimes. It is the domain of secondary rules which state the formation of law and its conformity with the supreme norm and the way they will be adjudicated. Hart further classifies secondary rules into three as recognition, change, and adjudication. Rule of recognition is the basic test to 
check the legitimacy of primary rule. Hart states that law is a complete system supervised internally. If the primary rule follows a certain procedure of enactment then the rule will be recognized otherwise it can be set aside. From rules of change, Hart means, the rules to describe how primary law will be amended. The third type of secondary rule is the rules of adjudication. These explain the remedial process in case of violation of primary rules. The authority to exercise these rules is with the judicial organs of the state. Hart explains:

"(Secondary Rules) may all be said to be on a different level from the primary rules, for they are all about such rules; in the sense that while primary rules are concerned with the actions that individuals must or must not do, these secondary rules are all concerned with the primary rules themselves. They specify how the primary rules may be conclusively ascertained, introduced, eliminated, varied, and the fact of their violation conclusively determined." (Hart, 1994, p. 151)

The framework of primary and secondary rule expounded by H.L.A. Hart takes law as an independent field of inquiry. He accepts the significance of morality for the codification of law but describes morality as an external not internal issue of law. Hart says that morality and law go side by side but denies the thesis of Natural Law theorists to put morality as a validation standard for law. He establishes the relationship between primary and secondary and makes both subservient to the constitutional law of state rather than morality. Hart concludes that law is something real and operates in real-world rather than "laws in philosopher's heaven" idealization (Start, 1984, p.673).

\section{Ronald Dworkin's Discourse on Interpretive Methods}

Ronald Dworkin evaluated Hart's philosophy of law as incomplete falling short of many essential criteria. He described it as lacking moral and descriptive aspects of the law. The interpretive approach of Dworkin opened a debate that further fortified the way for Inclusive Legal Positivism. The Hart-Dworkin debate of legal positivism has led towards the adoption of two distinct approaches called inclusive and exclusive legal positivism. The inclusive approach is also termed as soft and the exclusive as the hard one. The former does not feel moral or traditional grounds sufficient for legal interpretations and later approach although segregates law and morality but admits the significance of morality as Hart says that both go side by side but the law cannot be under the control of morality rather operates independently. Dworkin's approach towards legal positivism is in contrast with H.L.A. Hart.

Ronald Dworkin put objections to the thesis of Legal Positivism on account of various descriptions of the system of rules only that excludes principles. He described the failure of Legal Positivism to address the issue of principles. Dworkin also mentioned the dichotomy of legal validity from legal norms against standards of the legal system. He rather emphasized legal validity under legal norms based upon morality. Dworkin is famous for his Interpretative theory. He expounded that there always lies a 'right answer' too hard cases. Dworkin comments, "Judges should decide hard cases by interpreting the political structure of their community in the following, perhaps special way: by trying to find the best justification they can find, in principles of political morality, for the structure as a whole, from the most profound constitutional rules and arrangements to the details of, for example, the private law of tort and contract." Dworkin stresses that the interpretation for being successful must follow the practices of the society in certain cases. Moreover, it must speak about moral justifications and standards. He explained the process of interpretation by judges in the following words: 
"A thoughtful judge might establish for himself, for example, a rough "threshold" of fit which any interpretation of data must meet to be "acceptable" on the dimension of fit, and then suppose that if more than one interpretation of some part of the law meets this threshold, the choice among these should be made, not through further and more precise comparisons between the two along that dimension, but by choosing the interpretation which is "substantively" better, that is, which better promotes the political ideals he thinks correct."(Dworkin, 1982, p.165)

Dworkin describes the process of interpretation by adjudication as like jurisprudential theory. He declares judges' opinions in particular cases are endeavors of legal philosophy (Dworkin, 1982, p.171).

Ronald Dworkin contradicted his approach towards the idea of rule-focused Legal Positivism. The latest work of Dworkin puts forward the idea of similitude between rules and principles (Dworkin, 1968, p.90). Ronald Dworkin tried to establish the fallacy of Rule of Recognition by Hart but faced criticism for his theories. He criticizes the Social Fact Thesis of internal and external points of view about law expounded by Hart. In response, Hart proposes the philosophy of Dworkin in contrast with the basics of Legal Positivism. Hart notes:

"We all -at least all lawyers-share a concept of law and legal rights, and we contest different conceptions of that concept. Positivism defends a particular conception, and I have tried to defend a competing conception. We disagree about what legal rights are in much the same way as we philosophers who argue about justice disagree about what justice is. I concentrate on the details of a particular legal system with which I am especially familiar, not simply show that positivism provides a poor account of that system, but to show positivism provides a poor conception of the concept of a legal right." (Dworkin, 1968, p.81)

The writings of Ronald Dworkin accommodate morality in law through interpretive theory. He takes morality as an inside affair of the legal framework while Hart considers it out of the legal framework. Dworkin, in his writings, has not given certain criteria or pictures of his conceptualization of morality, and Dworkin's model only fits United States' constitutional orientation, not the other societies. It is pertinent to infer that the Interpretive Approach of Dworkin may lead towards strong judicial activism and control of the judiciary over the constitution. This phenomenon will affect the balance among various organs of the state.

\section{Hart and Fuller Arguments over Morality}

Lon Fuller is a $20^{\text {th }}$-century jurist who criticized the positivist thesis and entered into debate with H.L.A. Hart on the question of the dichotomy of law and morality. Fuller, a natural law theorist, and writer deemed morality as a controlling object of the law. The main theme of his book 'Morality of Law' was the determination of law subservient to the collective morality of society. Fuller in his article titled 'Positivism and Fidelity of Law; a reply to Professor Hart' replied to the thesis forwarded by H.L.A. Hart regarding the independent operation of law from morality in his famous article 'Positivism and separation of law and Morals' (Pavone, 2017).

Lon Fuller described the thesis of Legal Positivism based on a fallacy. He targeted Austin's command theory on account of its tendency of establishing absolute rule. Fuller described 
Fuller targeted Hart's 'Minimum Content Approach' as a way towards the naturalist approach (Fuller, 1964, p. 159). Moreover, the criticism was targeted at the notion of the judge's interpretive approach towards law. Fuller says that positivist judges sometimes use morality to interpret the statute in hard cases and that process is based upon morality. He described every legal system got some moral standards to achieve. Fuller criticized the concept of the legal system as self-floating by Hart (Fuller, 1964, p. 159). Hart's description of law comprised of command, sovereignty, and sanction as self-floating was refuted by Fuller as according to him a legal system cannot work independently rather it follows some highest norms of society. Fuller also explained the problem of penumbra in law as sometimes statute does not contain a certain meaning and to ascertain the meanings of a certain term, judges need external sources for the interpretation and those are not law. This problem of penumbra explains that law cannot work on its own rather needs external morality to set its way (Fuller, 1958, p. 630). Moreover, the case of war crimes may be taken as a point to question the thesis of Legal Positivism. To illustrate, a woman informed Hitler's administration about his husband's role as a spy in war. The husband was hanged and after the war, a trial was held against the wife. She argued that she has done nothing wrong by following the law of the land. According to the positivist approach, she did no wrong and no punishment can be made (Fuller, 1958, p. 630). But naturalist thinkers establish that an immoral law is not law and she was not duty-bound to follow a wrong law. Fuller further elaborated eight criteria for legislation as the law should be existent, not ad-hoc, the law must be promulgated and made known to people, the law should be prospective not retrospective, the law is comprehensive and clear for interpretation, the law is supposed to be consistent in its contents, possibility of being obeyed, durability and its application by state authorities.

The arguments Fuller was replied to by Hart in his famous work 'The Concept of Law' that was the upgraded format of Hart's article and the book almost covered the arguments of Fuller in the following order. For, the question of interpretation, Hart describes and examples of laws restricting vehicles in the park. Hart discusses the example of a bicycle being taken as a vehicle or not (Fuller, 1958, p. 630). Fuller's point of view says that interpretation will be done by external sources but in contrast to the arguments of Fuller, Hart says that the word vehicle is used to save pollution, and the intention of the legislature will be taken from the law itself not from some external sources. Hart argues that interpretation follows the internal structure of law rather than external morality for interpretation. Interpretation is done by the judiciary in difficult situations also follows the internal philosophy of law rather than philosophical foundations of morality. This interpretation is under cannons of interpretation described by law and precedents. Hart argues the legal system is self-floating as law follows its morality. Hart puts forward his thesis of the 'Minimum Content Approach' of Inclusive Positivist approach to use morality for the least possible and need-based in case of very hard necessity. Hart further argues that even in this approach law will not be subservient to morality rather this interaction of law and morality will lead towards fortification of law itself. Tommaso Pavone from Princeton University has written a brief about the Hart-Fuller debate in his article, 'A Critical Adjudication of the Fuller-Hart Debate'. He described Fuller's work as supportive to the work of Hart rather critical. Pavone had deliberated on Fuller's concepts of the morality of aspiration and morality of duty in detail. By morality of aspiration, Fuller tries to explain the concepts of a good life, aesthetics, and kinship, etc (Pavone, 2017). Meanings of the morality of duty are mentioned as rules to keep order in society. He illustrates that at the fundamental level morality of duty operates and at the highest level morality of aspiration controls the society. Fuller's approach is rejected by Hart and Pavone on the notion of establishing an abstract control over certain laws. His conception of the morality of aspiration may be interpreted in a thousand manners and rules will lose 
certainty in case of making duty under morality. Pavone also criticized the eight conditions for law and concept of internal morality of law by Fuller that a law made by sovereign may fulfill the internal morality criteria as well as all eight conditions to become law even the law remains unjust.

\section{John Rawls on Original Position}

John Rawls conceptualized the recent era of plural society and globalization and suggested some tools to attain justice and fairness in legislation. He authored many books to put forward his ideas for the attainment of justice and fairness by describing the theory of Original Position and the Veil of Ignorance. Although his theories were scrutinized by Amartya Sen (Sen, 2009) and other philosophers as idealistic and not practical they impact substantially on modern trends of legislation. Rawls philosophy of justice as fairness can be understood from the following text:

"The question of fairness arises when free persons, who have no authority over one another, are engaged in a point activity and among themselves settling or acknowledging the rules which define it and which determine the respective shares in its benefits and burdens. A practice will strike the parties as fair if none feels that, by participating in it, they or any of the other are taken advantage of, or forced to give in to claim which they do not regard as legitimate." (Rawls, 1985, p.223)

The same stance is explained in the work of Rawls 'A Theory of Justice' as fair procedure and further described that fairness is something voluntary and justice as involuntary. $\mathrm{He}$ describes the hypothetical phenomenon of fairness and justice through his famous theory of Original Position under Veil of Ignorance.

Rawls devised a hypothetical foundation for the attainment of fairness while constructing the rules of justice. He describes that every human gets some influence and background for his status in society and miseries (Rawls, 1999, p.59). These various influences do not let a human reach a status of fairness while making society rules. Unlike Plato who attributed justice as an internally harmonious ordered society, Aristotle who names it equality, or Fred Feldman's idea of what one deserves (Feldman, 2016), John Rawls focuses on fairness as the cause for justice (Freeman, 2007). He further elaborates justice as some system to distribute both benefits and burdens devised by both political and social standards in a manner that is fair to all members of society. To illustrate his hypothetical conception, Rawls puts forward the 'Thought Experiment'. Rawls says that rules of justice can be made by individuals who are free from various socio-political influences, mutually disinterested and rational persons. He gives the criteria of fairness for those people as without any selfish interests, not involving good fortune or luck, and without any consideration to social circumstances of individuals. Rawls describes epistemic constraints as personal gain, position, race, gender, power, intelligence, age, social standing, and values. He names freedom from these influences as Veil of Ignorance. This Veil of Ignorance does not preclude the individuals who are devising rules of justice from their knowledge of scientific, biological, and psychological rules. Rawls describes that an individual under the Veil of ignorance from socio-political influences and rationale will lead towards just rules meeting the criteria of justice.

John Rawls's theory of justice and fairness are criticized mainly on account of its idealistic approach. The work of Rawls is nearer to Platonic idealism and is described as hard to 
achieve practically in this world where individuals sympathize with political, social, economic, and religious ideals.

\section{Conclusion}

The study has systematically examined the debate for mapping the role of morality in law. It finds that the law and morality are two distinct norms that regulate human behavior in a society. The normativity of law solely depends on the state and it has liberated itself from the normative framework of morality. The debate of H.L.A. Hart and Lon Fuller is significant in deciding the interaction between law and morality. The systematic study of the work of philosophers, in this study, aims at educating the reader with a fundamental construct of legislative trends in modern states.

\section{References}

Austin, J. (1995) The Province of Jurisprudence Determined, ed. Wilfred E. Rumble. Cambridge University Press.

Austin, J. (2002) Lectures on Jurisprudence. Bloomsbury Academics. Volume 1.

Bentham, J. (2008) An Introduction to the Principles of Morals and Legislation. Read Books.

Bhardwaj, P. (2015) Legal Positivism; an Analysis of Austin and Bentham. International Journal of Law and Jurisprudential Studies. 1(6).

Bix, H. B. (2005) 'Legal Positivism', in Martin P. Golding, William A. Edmundson (eds.), The Blackwell Guide to the Philosophy of Law and Legal Theory. Blackwell Press.

Campbell, R. (1879) The Philosophy of Positive Law.

Demiray, M.R. (2015) Natural Law Theory, Legal Positivism, and the Normativity of Law.The European Legacy; Towards New Paradigms.

Dworkin, R. (1982) Natural Law Revisited. University of Florida Law Review. 32 (2).

Dworkin, R. (1986) Law’s Empire. Harvard University Press.

Feldman, F. (2016) Distributive Justice: Getting What We Deserve From Our Country. Oxford University Press.

Freeman, S. (2007) Lectures On History Of Political Philosophy By John Rawls. Harvard University Press.

Fuller, L.L. (1964) The Morality Of Law. Yale University Press.

Fuller, L.L. (1985) Positivism And Fidelity To Law Harvard Law Review. 17 (4).

George, R. P. (1992) Natural Law Theory: Contemporary Essays. Clarendon Press.

George, R.P. (2008) Natural Law. Harvard Journal of Law \& Public Policy. 31.

Hart, H.L.A. (1965) Review Of The Morality Of Law. The Harvard Law Review. 78.

Hart, H.L.A. (1994) The Concept Of Law. Oxford University Press. 
Kelsen, H. (1934) Introduction to the Problems of Legal Theory, trans. B.L. Paulson, S.L. Paulson. Clarendon Press.

Pavone, T. A Critical Adjudication Of The Fuller-Hart Debate' Retrieved from: http://tommasopavone.yolasite.com/resources/Fuller-Hart\%20Debate\%20(Critical\% 20Review).pdf. accessed 21 June 2017.

Rawls, J. (1985) Justice As Fairness: Political And Metaphysical. Philosophy and Public Affairs 14.

Rawls, J. (1999) The Theory Of Justice. Oxford University Press.

Sen, Amartya. (2009) The Idea of justice. Harvard University Press.

Shield, H., (2017) John Rawls and the Veil of Ignorance' (2013).

Star, C.W. (1984) Law and Morality in H.L.A. Hart's Legal Philosophy. Marquette Law Review. 67 (4). 